Journal of Bangladesh Academy of Sciences, Vol. 37, No. 2, 173-187, 2013

\title{
CHROMIUM IN URBAN SOIL-PLANT-WATER ECOSYSTEMS
}

\author{
M. N. MONDOL ${ }^{*}$, A. S. CHAMON, B. FAIZ AND S. F. ELAHI \\ Department of Soil, Water and Environment, University of Dhaka, Dhaka-1000, \\ Bangladesh
}

\begin{abstract}
Heavy metal pollution is associated with public health concerns. The study was conducted at the vicinity of the Tejgaon industrial area $\left(8 \mathrm{~km}^{2}\right)$ adjacent to Dhaka City Corporation. To investigate the seasonal extent of soil-water ecosystems pollution with chromium discharged from the industries, municipality, and slums, and its transfer co-efficiency into plants or crops. Composite soil, plant and water were randomly collected from industrial sites by GPS guided sampling procedure during wet and dry seasons, processed, and analyzed. Soils were analyzed for particle size distribution (sand, silt and clay), $\mathrm{pH}$, electrical conductivity (EC), total organic carbon, water-soluble, ammonium acetate extractable, DTPA extractable and total chromium. Plant samples were analyzed for total $\mathrm{Cr}$ concentration. Water samples were analyzed for $\mathrm{pH}, \mathrm{EC}$, and dissolved $\mathrm{Cr}$ concentration. During wet season, the average Cr concentration was 0.16, 0.72, 1.51 and $68 \mathrm{mg} / \mathrm{kg}$, and in the dry season the concentrations were 6.60,12.44, 23.1 and $248.3 \mathrm{mg} / \mathrm{kg}$ as water-soluble, $\mathrm{NH}_{4} \mathrm{OAc}$ and DTPA extractable and total, respectively. Total $\mathrm{Cr}$ concentration was $248.3 \mathrm{mg} / \mathrm{kg}$, which was more than 2 times higher than the tolerable limit. Plant samples accumulated more and tolerated higher amounts of $\mathrm{Cr}$ during dry season. During dry season, more than $47 \%$ of water samples were found above the WHO standard level.
\end{abstract}

Key words: Season, Tejgaon soil, Chromium, Heavy metal, Pollution

\section{INTRODUCTION}

Bangladesh has at present about 30,000 large and small industrial units. Industrial wastes and effluents are being discharged randomly into the soil, water system (canals, rivers, etc.), road-sides, and in the vicinity of the industrial operations without any treatment in Bangladesh. They pollute productive soils, natural water systems as well as ground water. Their uptake and accumulation in plants have been known to result in negative effects on plants growth (Chamon et al. 2005). The uptake of heavy metals by plants from contaminated soils is of great interest because an excess of dietary intake of some of these metals (e.g. $\mathrm{Cr}$, $\mathrm{Pd}, \mathrm{Cd}$ ) might be deleterious to the health of the consumers.

The important heavy metals discharged from Tejgaon industries in Bangladesh are cadmium, lead, chromium, mercury, zinc, and in few cases copper and manganese (Ullah

* Corresponding author: <mondol-Bangladesh@hotmail.com>. 
et al. 1999, Chamon et al. 2005). Chromium is quite often released into the environment from tanneries, laboratory analysis, electroplating, metal finishing, mining, paint and dye stuff, duplicating, rubber and plastics, textile industries, oxidants and cleaning agents (Schmidtke 1980). It is more important to know the distribution of trace metals in different forms, than just the total content (Petruzzelli 1989).

The Tejgaon industrial area is low-lying and wet through most part of the year. This part is influenced by the battery, biscuit, paper and pulps, textiles, carbides, pharmaceuticals, pesticides, distilleries etc. where all effluents and wastes converse and the zone under investigation is designated as the confluence zone by which the heavy metals were elevated. Low $\mathrm{pH}$ values in the respective sites could possibly increase to solubility and mobility of metals in the soils. Increased solubility of metals is likely to $\mathrm{Cr}$ to increased availability of the metals for plant uptake, and it might cause $\mathrm{Cr}$ toxicity. The results indicate that appreciable soil acidification has taken place in the vicinity of that area. This is an agreement with the result from other investigators (Ullah et al. 1999, Chamon et al. 2005). During the course of the present research, soils, plant and water samples were collected and analyzed by various independent extractant for characterization of the $\mathrm{Cr}$ species in soils and their subsequent concentration into plants and water.

In a study with Hazaribagh soil, Bangladesh, irrigation with contaminated sewage effluents from the leather industry resulted in very high concentrations of $\mathrm{Cr}$ and other metals in rice plants, and concentrations of these elements were much greater in leaves than in grains (Chamon et al. 2005). Kashem and Singh (1998) and Ullah et al. (1999) reported that the hazaribagh tannery area was highly contaminated with $\mathrm{Cr}, \mathrm{Zn}$ and $\mathrm{Cu}$. Metal contaminations of soils, sediments and water bodies and plants at Hazaribagh soils have also been reported by Kashem and Singh (1998). High concentrations of Cr or other elements in soil can be phytotoxic to crop plants, which can cause reduction in crop growth and yield. Chromium was found to be phytotoxic on the germination and seed yield of peas. Critical toxic levels of $1.0-2.0 \mathrm{mg} / \mathrm{kg}$ of $\mathrm{Cr}$ in plants general and 5-20 $\mathrm{mg} / \mathrm{kg}$ in young barley crop were reported by Sauerbeck (1982). Chromium is a highly toxic heavy metal for microorganisms, humans, animals and plants. Due to its widespread industrial use, it has become a serious pollutant in a diverse array of environments (Kashem and Singh 1998).

The aims of the present study was to investigate (1) the $\mathrm{Cr}$ species of soil using different extractant during wet and dry season, (2) The concentration of $\mathrm{Cr}$ in urban soil, plant and water ecosystem, and 3) the seasonal effects on $\mathrm{Cr}$ concentration in different species of plants. 


\section{MATERIAL AND METHODS}

Description of the study area: The study was conducted at the vicinity of the Tejgaon industrial area $\left(8 \mathrm{~km}^{2}\right)$ adjacent to Dhaka City Corporation, and is only about 5 $\mathrm{km}$ north of the City Center (Fig. 1). The study area consisted of two distinct components, one was the large shallow swampy area (lagoon) bordering Tejgaon industrial area, which received the unregulated discharge, drainage, and surface runoff from the surrounding classified and unclassified industries (Tejgaon soil series), and residential (Kajla soil series) and slum areas (Payati soil series) (e.g. Gulshan model town, Niketan Housing Society, Begunbari and other adjoining residential and slums). The other component (floodplain area i.e. Karail soil series) consisted of an earthen canal which received the overflow from the lagoon and drained into nearby Balu, Sitalakha, and Buriganga river, respectively.

Bangladesh has a tropical climate, which, according to Koppens system can be described as Monsoon savannah (North), tropical savannah (W-E) and tropical rainforest (S-SE). The major seasons are the pre-monsoon season (April-May), the hot monsoon season with heavy rain falls (June-September), the post monsoon season (OctoberDecember) and the relatively cooler and dry winter season (December-March). The yearly precipitation varies from $1500 \mathrm{~mm}$ (W) to $5700 \mathrm{~mm}$ (NE) (Hussain 1992). Mean annual temperature is about $25^{\circ} \mathrm{C}$. Mean monthly temperature ranges between $17^{\circ} \mathrm{C}$ in January and $30^{\circ} \mathrm{C}$ in April-May. Average across the sampling sites, the sand content ranged between 17 and $37 \%$, silt content 31 and $61 \%$, clay content 22 and $32 \%$, and organic matter content 4.1 and $5.9 \%$. It receives domestic raw sewage from surrounding habitation; so also the activities like cattle washing, cloth washing, bathing, and other activities (laundry) paves the way for environmental pollution.

Sampling, processing and analysis of soil, plant and water samples: Composite soil, plant and water samples were randomly collected from 42 geo-referenced sites in 5 different land-use/land covers during wet: September 2006 and dry: January 2007 seasons. Five composite pseudo-replicated soil, plant, and water samples of each were collected from each land-use/land cover category. The field-moist soil samples were airdried for 7 days at room temperature $\left(25^{\circ} \mathrm{C}\right)$, ground, with mortar and pestle, and sieved through a $2 \mathrm{~mm}$ mesh before analysis. The existing vegetation at each replicated site was collected, identified and classified, and oven-dried at $65^{\circ} \mathrm{C}$ until a constant weight was obtained. The dried samples were ground and passed through a $2 \mathrm{~mm}$ sieve prior to analysis. Water samples were collected in dry, clean polyethylene bottles $(500 \mathrm{ml})$ fitted with liquid-tight stopper. The water samples were filtered using Whatman ${ }^{\circledR} 42$ filterpaper, and analyzed within 7 days of collection. 
Soil $\mathrm{pH}$ was determined using a combination glass electrode after 30 min shaking with distilled deionized water. Electrical conductivity (EC) was measured in 1:1 soilwater slurries using a conductivity meter. Soil organic carbon was measured on finely grounded $(<200 \mu \mathrm{m})$ air-dried samples using the Walkey-Black wet oxidation method (Sparks et al. 2001). The particle size analysis of soil (sand, silt and clay) was done by following standard hydrometer method (Black et al. 1979). Exactly $2 \mathrm{~g}$ of soil samples in $50 \mathrm{ml}$ polypropylene tubes were shaken with distilled deionized water to extract and measure water-soluble Cr (Sparks et al. 2001). The soil: water suspension was filtered to obtain clear aliquot. For extractable $\mathrm{Cr}$, soil samples were shaken with $1 \mathrm{M} \mathrm{NH} 4 \mathrm{OAc}$ at 1:10 (Sparks et al. 2001) followed by filtration to collect clear aliquot. The DTPA extractable $\mathrm{Cr}$ was measured after extracting the soil samples with DTPA solution at 1:2 (Sparks et al. 2001). The suspensions were filtered to obtain clear aliquot. For total $\mathrm{Cr}$ (non-crystalline fraction) analysis, soil samples were digested with concentrated $\mathrm{HCl}$ and $\mathrm{HNO}_{3}$ at 3:1 (Blum et al. 1996). After acid digestion, the digestate samples were diluted with distilled deionized water.

Water $\mathrm{pH}$ was measured using a combination glass electrode meter. Electrical conductivity (EC) of the water was measured by using a conductivity meter. For plant biomass $\mathrm{Cr}$ content, a $1 \mathrm{~g}$ sample of processed plant biomass was taken into a $100 \mathrm{ml}$ Kjeldahl flask and digested with $10 \mathrm{ml}$ concentrated $\mathrm{HNO}_{3}$ followed by $2 \mathrm{ml}$ concentrated $\mathrm{HClO}_{4}$. After digestion, the aliquot was diluted with distilled deionized water and analyzed for plant biomass $\mathrm{Cr}$ concentration. The $\mathrm{Cr}$ concentration in soil, plant, and water samples were determined by atomic absorption spectrophotometer in Center for Advanced Research in Physical, Chemical, Biological and Pharmaceutical Sciences laboratory of the Dhaka University, Dhaka, Bangladesh.

Statistical analysis: The soil, plant, and water data were analyzed by the ANOVA procedure of the SAS. Using a least significant difference (LSD) test at a $\mathrm{p} \leq 0.05$, the treatment means were separated unless otherwise mentioned.

\section{RESULTS AND DISCUSSION}

Soil pH, electrical conductivity and chromium concentration: Average across season and site, the minimum value of $\mathrm{pH}$ was 6.3 and the maximum 7.0. High buffering capacity resulting from high soil organic matter content (4.87-11.55\%) probably influenced soil $\mathrm{pH}$ value. There was no wide variation in $\mathrm{pH}$ values among the wet and dry season. The average $\mathrm{pH}$ value was 6.7 and 6.5 during wet and dry season, respectively (Table 1). The minimum $\mathrm{pH}$ value was 6.3 recorded during dry seasons around the slum area (Payati soil series) (Table 1). The $\mathrm{pH}$ was slightly acidic in dry season (Table 2) probably due to the release of acids through decomposition of organic 
matter. The majority of bacteria and other organisms can flourish best in neutral environment and any change in $\mathrm{pH}$ affects them adversely. Bhouyan (1979) reported that sometimes the $\mathrm{pH}$ of the environment abruptly changed near the point of waste discharges which may kill the bacteria and hampering the self purification process of the river systems. Soil $\mathrm{pH}$ influences the physicochemical properties of soil, water body, activity of organisms, potency of toxic substances present in the soil and aquatic environment (Rouse 1979).

Electrical conductivity (EC) $(25-551 \mu \mathrm{S} / \mathrm{cm})$ and organic matter (OM) (4.87$11.55 \%$ ) were also influenced by the industrial wastes and effluents of the factories. Electrical conductivity usually used for indicating the total concentration of the ionized constituents of water. It is closely related to the sum of the cations or anions as determined chemically, and it usually correlates closely with TDS (Rouse 1979). EC varied widely and significantly during wet and dry season in different areas (Tables 1 and 2). During the wet season, significantly higher EC values $(203.6 \mu \mathrm{S} / \mathrm{cm})$ were recorded around industrial area (Tejgaon soil series) and the lowest value $(76.7 \mu \mathrm{S} / \mathrm{cm})$ was recorded around mix (i.e. industrial/residential/slum) (Tejgaon/Kajla/Poyati soil series) areas. On the other hand, the significantly higher EC values $(826.3 \mu \mathrm{S} / \mathrm{cm})$ were recorded around slum area (Payati soil series) and the lowest value $(140.3 \mu \mathrm{S} / \mathrm{cm})$ were recorded around residential areas (Kajla soil series) during dry season (Table 1). Table 2 shows the significantly higher EC values which were recorded in dry season $(304.4 \mu \mathrm{S} / \mathrm{cm})$ than that of wet season $(129.6 \mu \mathrm{S} / \mathrm{cm})$. Discharge of huge quantities electrolytes from industries (Tejgaon soil series) and slum areas (Payati soil series) may be the reasons for higher EC in dry season (Rande 2000). A significant sharp fall of EC in wet season might be due to huge dilution of the sampling areas by the monsoon rainfall.

The concentration of $\mathrm{Cr}$ ranged from 0.04-0.25, 0.37-1.14, 0.58-2.08 and 35.0-84.1 $\mathrm{mg} / \mathrm{kg}$ in water-soluble, $\mathrm{NH}_{4} \mathrm{OAc}$ extractable, DTPA extractable and total fractions respectively (Table 1). Total concentration of $\mathrm{Cr}$ at the industrial source point (Tejgaon soil series) $(84.1 \mathrm{mg} / \mathrm{kg})$ showed significantly the highest value than the other sites during wet season. But the other three $\mathrm{Cr}$ fractions (i.e. water-soluble, $\mathrm{NH}_{4} \mathrm{OAc}$ extractable and DTPA extractable Cr) were significantly higher at the floodplain area (Karail soil series) than the other sampling areas during wet season (Table 1). Similar results were also noted during dry season. Average total concentration of $\mathrm{Cr}$ during dry season, were 201.2, 255.3, 303.8, 229.8 and $235.0 \mathrm{mg} / \mathrm{kg}$ in floodplain (Karail series), industrial (Tejgaon series), mix (Poyati/Kajla/Tejgaon series), residential (Kajla) and slum areas (Payati series) which were above the tolerable total $\mathrm{Cr}$ concentrations of soil (Kloke 1980) (Table 1). 


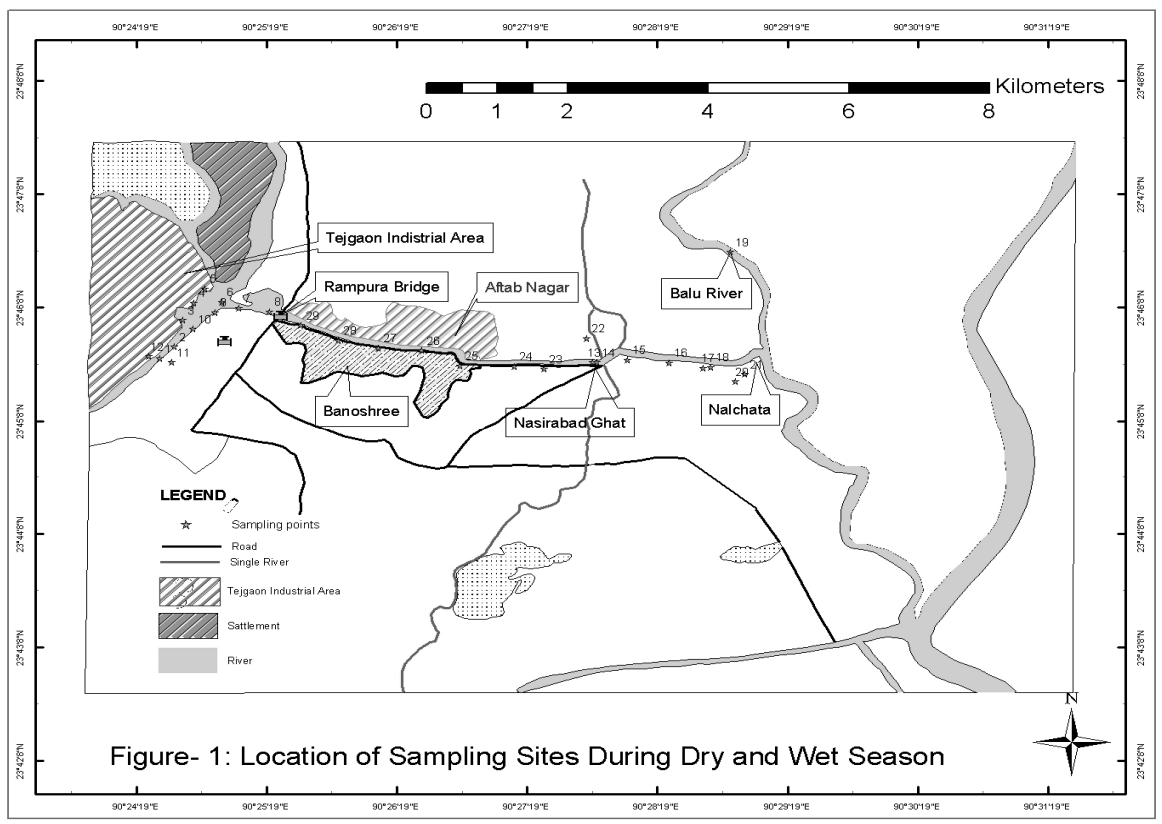

Fig. 1. Location of sampling sites during dry and wet season.

Total $\mathrm{Cr}$ concentration at the mix area (industrial/residential/slum) (Poyati/Kajla/ Tejgaon series), showed significantly the highest value $(303.8 \mathrm{mg} / \mathrm{kg})$ and flood plain area (Karail series) showed the lowest value $(201.2 \mathrm{mg} / \mathrm{kg})$ during dry season. Cr concentrations in water-soluble, $\mathrm{NH}_{4} \mathrm{OAc}$ extractable and DTPA extractable fractions ranged from 3.3-10.8, 6.9-20.7, 14.7-33.7 mg/kg, respectively (Table 1). The lowest value of water-soluble, $\mathrm{NH}_{4} \mathrm{OAc}$ extractable and DTPA extractable $\mathrm{Cr}$ fractions were observed in slum area (Payati series) and the highest in floodplain area (Karail series) during dry season. With increasing total soil $\mathrm{Cr}$ concentrations water soluble, ammonium acetate extractable fractions of $\mathrm{Cr}$ increased linearly. Discharge of huge quantities metals from industries, residential and slum areas may be the reasons for higher concentrations in dry season (Rande 2000). A significant sharp fall of metal concentrations in wet season might be due to huge dilution of the sampling areas by the monsoon rainfall. During 1st sampling period, (i.e. in rainy season) dilution of water was due to influx of rain water and floodwater from surrounding areas. Fresh water diluted and washed away much of the pollutants. But it was not enough to completely wash pollutants away. As water receded and pollution load in soil increased with dry season, heavy metals concentration increased 2 to 3 times than that during rainy season. During the wet season (from April to October) the pollution was visibly low because of heavy rainfall; most of the suspended materials, which were not complexed and precipitated with soil, organic matter and other reactive compounds, were flushed out through the canal into the 
adjoining vast flood zone area of the Balu river. However, during dry season (November to March), the soil and water were loaded with the pollutants.

The decreasing tendency with distance indicates the accumulation of $\mathrm{Cr}$ by the industrial operations. Similar findings were also observed by other investigator (Nuruzzaman et al. 1998) reported a very drastic decrease in metal concentration away from the source point. The Tejgaon industrial area is low-lying and wet through most part of the year. This part is influenced by the battery, biscuit, paper and pulps, textiles, carbides, pharmaceuticals, pesticides, distilleries etc., where all effluents and wastes converse and the zone under investigation is designated as the confluence zone by which the heavy metals were elevated. Low $\mathrm{pH}$ values in the respective sites could possibly increase the solubility and mobility of metals in the soils. Increased solubility of $\mathrm{Cr}$ around floodplain areas (Karail series) is likely to lead to increased availability of the metal for plant uptake and it might cause Cr toxicity.

Table 1. pH, electrical conductivity, and water-soluble, ammonium acetate and DTPA extractable, and total chromium contents of soil samples collected in wet and dry seasons.

\begin{tabular}{|c|c|c|c|c|c|c|c|}
\hline \multicolumn{8}{|c|}{ Wet season } \\
\hline Sampling sites & Soil series & $\begin{array}{c}\mathrm{pH} \\
(1: 1)\end{array}$ & $\begin{array}{c}\text { EC } \\
(\mu \mathrm{S} / \mathrm{cm})\end{array}$ & $\begin{array}{c}\text { Water } \\
\text { Soluble } \mathrm{Cr}\end{array}$ & $\begin{array}{c}\mathrm{NH}_{4} \mathrm{OAc} \\
\text { ext. } \mathrm{Cr}\end{array}$ & $\begin{array}{l}\text { DTPA } \\
\text { ext. Cr }\end{array}$ & $\begin{array}{l}\text { Total } \\
\mathrm{Cr}\end{array}$ \\
\hline & & & & \multicolumn{4}{|c|}{$\mathrm{mg} / \mathrm{kg}$} \\
\hline Floodplain & Karail & $6.8 \mathrm{ab}$ & $124.1 \mathrm{~b}$ & $0.25 \mathrm{a}$ & $1.14 \mathrm{a}$ & $2.08 \mathrm{a}$ & $70.2 \mathrm{~b}$ \\
\hline Industrial & Tejgaon & $6.5 b$ & $203.6 \mathrm{a}$ & $0.1 \mathrm{ab}$ & $0.48 \mathrm{bc}$ & $1.34 \mathrm{ab}$ & $84.1 \mathrm{a}$ \\
\hline Mixed & Poyati/Kajla/Tejgaon & $7.0 \mathrm{a}$ & $76.7 \mathrm{c}$ & $0.12 \mathrm{ab}$ & $0.88 \mathrm{ab}$ & $1.34 \mathrm{ab}$ & $66.5 \mathrm{~b}$ \\
\hline Residential & Kajla & $6.4 \mathrm{~b}$ & $113.0 \mathrm{~b}$ & $0.04 \mathrm{~b}$ & $0.37 \mathrm{c}$ & $0.58 \mathrm{~b}$ & $35.0 \mathrm{c}$ \\
\hline Slum & Payati & $6.9 \mathrm{a}$ & $130.8 \mathrm{~b}$ & $0.05 \mathrm{~b}$ & $0.42 \mathrm{bc}$ & $1.09 \mathrm{~b}$ & $66.7 \mathrm{~b}$ \\
\hline \multicolumn{8}{|c|}{ Dry season } \\
\hline Floodplain & Karail & $6.5 \mathrm{~b}$ & $163.7 \mathrm{~b}$ & $10.8 \mathrm{a}$ & $20.7 \mathrm{a}$ & $33.3 \mathrm{a}$ & $201.2 \mathrm{~b}$ \\
\hline Industrial & Tejgaon & $7.0 \mathrm{a}$ & $207.3 \mathrm{~b}$ & $6.7 \mathrm{~b}$ & $12.1 \mathrm{~b}$ & $23.7 \mathrm{~b}$ & $255.3 \mathrm{ab}$ \\
\hline Mixed & Poyati/Kajla/Tejgaon & $6.1 \mathrm{c}$ & $184.3 \mathrm{~b}$ & $6.1 \mathrm{~b}$ & $12.6 \mathrm{~b}$ & $20.0 \mathrm{bc}$ & $303.8 \mathrm{a}$ \\
\hline Residential & Kajla & $6.7 \mathrm{~b}$ & $140.3 \mathrm{~b}$ & $7.3 \mathrm{~b}$ & $12.6 \mathrm{~b}$ & $26.3 \mathrm{ab}$ & $229.8 \mathrm{ab}$ \\
\hline Slum & Payati & $6.3 \mathrm{c}$ & $826.3 \mathrm{a}$ & $3.3 \mathrm{c}$ & $6.9 \mathrm{c}$ & $14.7 \mathrm{c}$ & $235.0 \mathrm{ab}$ \\
\hline
\end{tabular}

$\mathrm{NH}_{4} \mathrm{OAc}=$ Ammonium acetate, DTPA $=$ Diethylenetriaminepentaacetic acid, $\mathrm{EC}=$ Electrical conductivity, and $\mathrm{Cr}=$ Chromium. Means separated by same lower case letter within each column are not significantly different at $\mathrm{p} \leq 0.05$.

The results indicate that appreciable soil acidification has taken place in the vicinity of that area. This is an agreement with the result from other investigators (Chamon et al. 2005). Seasonal effects on $\mathrm{Cr}$ fractionation were clearly observed in this investigation. The distribution of metals between the specific forms varies widely according to the individual metal and the characteristics of the wastes. These parameters include $\mathrm{pH}$, 
temperature, oxidation-reduction potential and the presence of complexing ligands. Total trace metal composition of soil is of little importance in determining its uptake by plants and consequently, in contaminating the food chain since the different forms have different mobilities, bioavailabilities and potential environmental contamination potential. It is more important to know the distribution of each trace metals in the different forms, than just the total content (Petruzzelli 1989). As a whole, the Tejgaon industrial area soils had the highest concentration of total $\mathrm{Cr}$ in floodplain (Karail series), industrial (Tejgaon series), mix (Poyati/Kajla/Tejgaon series), residential (Kajla series) and slum areas (Payati series), which might be due to discharge of liquid wastes, flocculated sludge and other solids with excessive metals coming from different industrial processes. The highest concentration of $\mathrm{Cr}$ and other metals in this area is not only a problem with respect to plant nutrition and the food chain, they may constitute a direct health hazards as well. The area is not only occupied by industries but there are many slums' people around the complexes and on the bank of waste discharging channel. Recently many urban area/housing projects namely, Aftab Nagar, Banasri housing project, Niketon project etc. have developed on the bank of waste discharging channel. So, these may be ecological implications associated with metal poisoning to the slums living children because they have direct contact with the contaminated soil and effluents (Cheung and Gu 2007).

Table 2. Seasonal effects on $\mathrm{pH}$, electrical conductivity, and water-soluble, ammonium acetate and DTPA extractable, and total chromium contents of soil and water samples.

\begin{tabular}{|c|c|c|c|c|c|c|}
\hline \multicolumn{7}{|c|}{ Soil samples } \\
\hline $\begin{array}{l}\text { Sampling } \\
\text { Season }\end{array}$ & $\begin{array}{l}\mathrm{pH} \\
(1: 1)\end{array}$ & $\begin{array}{l}\mathrm{EC} \\
(\mu \mathrm{S} / \mathrm{cm})\end{array}$ & $\begin{array}{l}\text { Water } \\
\text { soluble } \mathrm{Cr}\end{array}$ & $\begin{array}{l}\mathrm{NH}_{4} \mathrm{OAc} \\
\text { ext. } \mathrm{Cr}\end{array}$ & $\begin{array}{l}\text { DTPA } \\
\text { ext. Cr }\end{array}$ & $\begin{array}{l}\text { Total } \\
\mathrm{Cr}\end{array}$ \\
\hline & & & \multicolumn{4}{|c|}{$\mathrm{mg} / \mathrm{kg}$} \\
\hline Dry & $6.5 \mathrm{a}$ & $304.4 \mathrm{a}$ & $6.8 \mathrm{a}$ & $12.9 \mathrm{a}$ & $23.6 \mathrm{a}$ & $245.0 \mathrm{a}$ \\
\hline Wet & $6.7 \mathrm{a}$ & $129.6 \mathrm{~b}$ & $0.11 \mathrm{~b}$ & $0.7 \mathrm{~b}$ & $1.3 \mathrm{~b}$ & $64.5 \mathrm{~b}$ \\
\hline \multicolumn{7}{|c|}{ Water samples } \\
\hline & $\mathrm{pH}$ & $\begin{array}{l}\text { EC } \\
(\mu \mathrm{S} / \mathrm{cm})\end{array}$ & $\begin{array}{l}\text { Dissolved } \\
\mathrm{Cr}(\mathrm{mg} / \mathrm{l})\end{array}$ & & & \\
\hline Dry & $7.1 \mathrm{a}$ & $829.7 \mathrm{a}$ & $0.042 \mathrm{a}$ & & & \\
\hline Wet & $7.0 \mathrm{a}$ & $767.5 \mathrm{a}$ & $0.024 \mathrm{~b}$ & & & \\
\hline
\end{tabular}

The highest concentration of total and extractable $\mathrm{Cr}$, was also due to effluents and solid wastes of chemical manufacturing, electroplating and metal finishing, tannery, mining, paint and dye, textiles, printing and duplicating industries. Water soluble, $\mathrm{NH}_{4} \mathrm{OAc}$ extractable and DTPA extractable $\mathrm{Cr}$ have been considered as available $\mathrm{Cr}$ (Lindsay and Norvell 1978). 
These $\mathrm{Cr}$ species should measure available concentration of $\mathrm{Cr}$ in the contaminated soils of Tejgaon industrial area. Considering the critical limits of DTPA extractant for Cr (Lindsay and Norvell 1978), some of the sampling points were above the critical limits. The concentration of $\mathrm{Cr}$ in the soil solution phase strongly increased with decreasing $\mathrm{pH}$ and increasing total content of this metal in the different sampling points. The similar results were also reported by many authors (Chamon et al. 2005, Nuruzzaman et al. 1995). The continuous use of industrial effluents and wastes waters containing heavy metals, on agricultural land may results in metal accumulation in surface soil. In concentration $>100 \mathrm{mg} / \mathrm{kg}$ of soil, $\mathrm{Cr}$ is carcinogenic (Kloke 1980). During dry season all samples were above the maximum tolerable limit. This metal is toxic to both plants and animals through their entry into food chain. Anthropogenic pollution of $\mathrm{Cr}$ and their phytotoxicities have been reported by many investigators (Ullah et al. 1999, Chamon et al. 2005). Cr concentration in soil mainly varies depending on variation in site and industrial activities. It was evident that very high level of $\mathrm{Cr}$ (22,500 to $29402 \mathrm{ppm}$ ) along with other metals was found at main disposal point at Hazaribagh tannery area, reported by Nuruzzaman et al. (1998). But in this study, at Tejgaon industrial area, total $\mathrm{Cr}$ concentration in soil, at main disposal point was observed 303.8 to $201.2 \mathrm{ppm}$. This variation might be due to differences of site and industrial activities between Hazaribagh and Tejgaon industrial area.

Table 3. pH, electrical conductivity, and dissolved chromium concentration of water samples in wet and dry seasons.

\begin{tabular}{llccc}
\hline \multicolumn{4}{c}{ Wet season } \\
\hline Sampling sites & Soil series & $\begin{array}{c}\mathrm{pH} \\
(1: 1)\end{array}$ & $\begin{array}{c}\mathrm{EC} \\
(\mu \mathrm{S} / \mathrm{cm})\end{array}$ & $\begin{array}{c}\text { Dissolved } \\
\mathrm{Cr}\end{array}$ \\
& & & $\mathrm{mg} / \mathrm{l}$ \\
\cline { 4 - 5 } Floodplain & Karail & $7.4 \mathrm{a}$ & $747.2 \mathrm{~b}$ & $0.02 \mathrm{ab}$ \\
Industrial & Tejgaon & $7.3 \mathrm{ab}$ & $612.6 \mathrm{~b}$ & $0.04 \mathrm{a}$ \\
Mixed & Poyati/Kajla/Tejgaon & $6.2 \mathrm{c}$ & $632.0 \mathrm{~b}$ & $0.01 \mathrm{~b}$ \\
Residential & Kajla & $6.7 \mathrm{~b}$ & $679.7 \mathrm{~b}$ & $0.03 \mathrm{a}$ \\
Slum & Payati & $7.2 \mathrm{ab}$ & $1166 \mathrm{a}$ & $0.03 \mathrm{a}$ \\
\hline & & & & \\
\hline Floodplain & Karail & $7.1 \mathrm{a}$ & $729.0 \mathrm{~b}$ & $0.087 \mathrm{a}$ \\
Industrial & Tejgaon & $7.2 \mathrm{a}$ & $822.0 \mathrm{~b}$ & $0.038 \mathrm{~b}$ \\
Mixed & Poyati/Kajla/Tejgaon & $7.2 \mathrm{a}$ & $716.5 \mathrm{~b}$ & $0.038 \mathrm{~b}$ \\
Residential & Kajla & $7.0 \mathrm{a}$ & $818.0 \mathrm{~b}$ & $0.023 \mathrm{~b}$ \\
Slum & Payati & $7.0 \mathrm{a}$ & $1063.3 \mathrm{a}$ & $0.026 \mathrm{~b}$ \\
\hline
\end{tabular}

Water $\mathrm{pH}$, electrical conductivity, and chromium concentration: During wet and dry seasons the $\mathrm{pH}$ of the water samples were around neutrality but EC value was 
significantly higher during dry season than wet season. Water samples collected from source point i.e. from industrial area showed significantly higher dissolved $\mathrm{Cr}(0.04 \mathrm{mg} / \mathrm{l})$ than the other samples during wet season. On the other hand, during dry season, $\mathrm{Cr}$ samples collected from flood plain area were above the DOE (2002) drinking water standard which was $0.087 \mathrm{mg} / \mathrm{l}$ (Table 3). Heavy monsoon water diluted $\mathrm{Cr}$ concentrations at the areas far from the source point and showed lower values during wet season. The case was just opposite during dry season. Water soluble $\mathrm{Cr}$ fraction carried out by rain water and deposited at the FA (Floodplain area) during dry season and may be the reason for its significantly higher concentration than the other areas (Table 3). Average $\mathrm{Cr}$ concentration during dry season was almost double than wet seasons (Table 2 and 3). The general water quality of the whole study area was extremely poor. Foul smell was so intense that some of the workers had to abandon the sampling protocol. Ullah $e t$ al. (1999) earlier investigated heavy metal pollution of soils and water and their transfer into plants in Bangladesh.

Existing vegetation and plant biomass chromium concentration: Heavy metal concentration in plant samples was measured high. Plant samples accumulated more and tolerated higher amounts of heavy metals. During wet season, plant samples collected from industrial (Tejgaon series) and slum areas (Payati series) showed significantly higher biomass $\mathrm{Cr}$ concentrations than the other areas like floodplain (Karail series), mix (Poyati/Kajla/Tejgaon series), and residential areas (Kajla series) which were above the plants general toxic concentration level (Sauerbeck 1982). Significantly higher biomass Cr concentrations were investigated in Bean (Lablab niger Medik) $(3.1 \mathrm{mg} / \mathrm{kg}$ ), Grass (Cynodon dactylon Pers.) (2.0-2.2 mg/kg), Kalmi (Ipomea aquatica Forsk) (1.7-4.8 $\mathrm{mg} / \mathrm{kg}$ ) and water hyacinth (Eichhornia crassipes Mart.) (0.5-3.3 mg/kg) samples which were above the plants general toxic concentration level (1-2 mg/kg, Sauerbeck 1982) (Table 4) during wet season. Kalmi (Ipomea aquatica Forsk) and water hyacinth (Eichhornia crassipes Mart.) samples which are aquatic plants uptake $\mathrm{Cr}$ from the effluents containing higher $\mathrm{Cr}$ concentrations. On the other hand, upland crops like bean/grass as are irrigated with industrial waste water with high $\mathrm{Cr}$ also contain significantly higher biomass $\mathrm{Cr}$ concentrations, during wet season. Similar results were also observed during dry season. Plant samples collected from industrial (Tejgaon series), residential (Kajla series) and slum (Payati series) areas showed significantly higher $\mathrm{Cr}$ concentrations than the other areas during dry season (Table 4). Around the industrial area, all plant samples i.e. Boro rice (Oryza sativa L.) $(2.2 \mathrm{mg} / \mathrm{kg}$ ), grass (Cynodon dactylon Pers.) $(2.4 \mathrm{mg} / \mathrm{kg})$, and tomato (Lycopersicon esculentum Mill) $(2.4 \mathrm{mg} / \mathrm{kg})$, showed significantly higher biomass $\mathrm{Cr}$ concentrations during dry season (Table 4). Other upland crops like cabbage (Brassica oleracea) $(2.6 \mathrm{mg} / \mathrm{kg}$ ), coriander (Coriandrum sativum L.) (2.8 mg/kg), bean (Lablab niger Medik) (3.8 mg/kg), tomato (Lycopersicon 
esculentum Mill) $(4.2 \mathrm{mg} / \mathrm{kg})$ grown around the slum/RA areas showed significantly higher biomass $\mathrm{Cr}$ concentration (Table 4). Average plant biomass concentration of $\mathrm{Cr}$ were 2.90 and $2.30 \mathrm{mg} / \mathrm{kg}$ during wet and dry season respectively, at Tejgaon industrial area which were above the plants general toxic concentration level (Sauerbeck 1982) (Table 4).

Aquatic plants $(2.8 \mathrm{mg} / \mathrm{kg})$ accumulated significantly higher $\mathrm{Cr}$ concentration than upland plants $(2.0 \mathrm{mg} / \mathrm{kg})$ during wet season, the case which was just opposite during dry season (Table 5). Bean (Lablab niger Medik) as an upland crop showed significantly higher biomass $\mathrm{Cr}$ concentration $(2.2-3.8 \mathrm{mg} / \mathrm{kg}$ ) which was above the plant general toxic concentration level (Sauerbeck 1982) during both seasons (Table 5). The total Cr content of the soils, water and plant samples showed wide range of values from background to a level considered to reflect severe contamination. The extent of contamination was identified by using information of the tolerable and in excess of tolerable level of total $\mathrm{Cr}$ in soils (Kloke 1980). Tolerable total concentration of $\mathrm{Cr}$ in soil is $100 \mathrm{mg} / \mathrm{kg}$ (Kloke 1980). The total $\mathrm{Cr}$ concentration of the soil samples at different points showed wide range of values reflects severe contamination. Concentrations of total $\mathrm{Cr}$ in soils during wet season were found below the tolerable level with few exceptions. But during dry season, $100 \%$ soil samples were found in the group of in excess of tolerable level $(\geq 100$ $\mathrm{mg} / \mathrm{kg}$ ) (Table 1). Biomass Cr concentration in plant samples around residential (Kajla series) and floodplain area (Karail series) were found in the group of 'within toxic level concentration (1-2 $\mathrm{mg} / \mathrm{kg}$ ) during wet season but similar trend were observed around floodplain (Karail series) and mix areas (Poyati/Kajla/Tejgaon series) during dry season. Whereas plant samples collected from industrial (Tejgaon series), mix (Poyati/Kajla/Tejgaon series), residential (Kajla series) and slum areas (Payati series) showed significantly higher biomass $\mathrm{Cr}$ concentrations which were found in excess of toxic level concentration ( $>2 \mathrm{mg} / \mathrm{kg}$ ) during dry season (Table 4). Bean, grass and Kalmi are the seasonally common aquatic and upland plants showed higher biomass $\mathrm{Cr}$ concentration (Table 6). Expeditions to collect samples were extremely difficult due to the foul smell and unknown nature of gases emitting out of the water body. The soil, water and air were unfit of any kind of human habitation. But a vast number of populations were living and working in the area disregarding the existing severe health hazards. Results show that the soil, water and plant were of extremely low quality in the rainy season. Their quality deteriorated several fold in the dry season. The $\mathrm{pH}$ dependence of the solution concentration of this element i.e., $\mathrm{Cr}$ shows that the mobility and availability of the metals is high at strongly to extremely acid soil reaction. This was also reported by Brümmer et al. (1988). During 1st sampling period, wet season saw dilution of water due to influx of rain water and floodwater from surrounding areas. Fresh water diluted and washed away much of the pollutants. But it was not enough to completely wash pollutants away. As water receded and pollution load increased with dry 
season (2nd sampling period), heavy metals concentration increased 2 to 3 times than that during rainy season. The different types of plant species collected from different locations are presented in Table 4.

Plants take up heavy metals from solution without any hindrance. During the rainy season most plants were grass and water hyacinth with a few other plants. Most of the grasses find their way into the food chain in the form of cattle feed. During the dry season rice, grass and many other types of 'rabi' crops, e.g., tomato, capsicum, cabbage, cauliflower, etc. were growing in the contaminated soils irrigated with these polluted water. $\mathrm{Cr}$ concentrations were very high and above critical level in all crops in both seasons except $\mathrm{Cr}$ content in rice and some grass. One of the most alarming facts is that some sampling points under investigation were apparently far from the pollution source. Bumper crops were being produced in the vicinity of Balu river. Consumers have no idea that locally produced crops with attractive appearances have high pollution content of heavy metals like $\mathrm{Cr}$. The $\mathrm{Cr}$ concentrations in soils with different extractant were found to decrease with distance away from the disposal point due to dilution of the effluent and water. Similar findings were also observed by other investigators (Chamon et al. 2005, Ullah et al. 1999). Heavy metals may accumulate in different parts of plants depending upon the plant species, soil condition, and types of heavy metal (Kabata-Pendias et al. 1993). Soil parameters (pH, organic matter content, cation exchange capacity etc) are known to affect the availability of heavy metals for uptake by plants (Kabata-Pendias et al. 1993).

\section{CONCLUSIONS}

The distribution of metals between the specific forms varies widely according to the individual metal and the characteristics of the wastes. These parameters include $\mathrm{pH}$, temperature, oxidation-reduction potential and the presence of complexing ligands. Total trace metal composition of soil is of little importance in determining its uptake by plants and consequently, in contaminating the food chain since the different forms have different mobilities, bioavailabilities and potential environmental contamination potential. It is more important to know the distribution of each trace metals in the different forms, than just the total content. The results show that the soil samples were of extremely low quality in the rainy season. Their quality deteriorated several fold in the dry season. Future research is necessary to delineate the quality and quantity of different organic and inorganic fractions in the total

environment. Food quality is an important issue for human survival and should be addressed with immediate urgency. Information on the pattern and distribution of heavy metals, accumulation and translocation in the edible plants from the sites of deposition in agricultural field receiving industrial wastewater would be helpful for the selection of suitable plant species that can be used as accumulator plant to minimize the concentration of these metals in the highly polluted soils. 
Table 4. Plants distribution and their biomass chromium concentration during wet and dry seasons.

\begin{tabular}{|c|c|c|c|c|}
\hline \multicolumn{5}{|c|}{ Wet Season } \\
\hline $\begin{array}{l}\text { Sampling } \\
\text { Sites/series }\end{array}$ & $\begin{array}{l}\text { Common name } \\
\text { of plants }\end{array}$ & $\begin{array}{l}\text { Scientific name } \\
\text { of plants }\end{array}$ & $\begin{array}{l}\text { Type of } \\
\text { plants }\end{array}$ & $\begin{array}{l}\text { Biomass Cr } \\
(\mathrm{mg} / \mathrm{kg})\end{array}$ \\
\hline \multirow{3}{*}{$\begin{array}{l}\text { Floodplain } \\
\text { (Karail series) }\end{array}$} & Grass & Cynodon dactylon Pers. & Upland & $2.2 \mathrm{c}$ \\
\hline & Kalmi & Ipomea aquatica Forsk & Aquatic & $1.7 \mathrm{~cd}$ \\
\hline & Water hyacinth & Eichhornia crassipes (Mart.) Sols. & Aquatic & $0.5 \mathrm{e}$ \\
\hline \multirow{5}{*}{$\begin{array}{l}\text { Industrial } \\
\text { (Tejgaon series) }\end{array}$} & & & & $1.5 \mathrm{C}$ \\
\hline & Bean & Lablab niger Medik & Upland & $3.1 \mathrm{~b}$ \\
\hline & Grass & Cynodon dactylon Pers. & Upland & $2.0 \mathrm{c}$ \\
\hline & Kalmi & Ipomea aquatica Forsk & Aquatic & $3.7 \mathrm{~b}$ \\
\hline & Water hyacinth & Eichhornia crassipes (Mart.) Sols. & Aquatic & $2.8 \mathrm{bc}$ \\
\hline & & & & $2.9 \mathrm{~B}$ \\
\hline Mixed & Kalmi & Ipomea aquatica Forsk & Aquatic & $4.8 \mathrm{a}$ \\
\hline Poyati/Kajla/Tejgaon & Water hyacinth & Eichhornia crassipes (Mart.) Sols. & Aquatic & $1.4 \mathrm{~d}$ \\
\hline \multirow{3}{*}{$\begin{array}{l}\text { Residential } \\
\text { (Kajla series) }\end{array}$} & & & & $3.1 \mathrm{~B}$ \\
\hline & Bean & Lablab niger Medik & Upland & $1.3 \mathrm{~d}$ \\
\hline & Grass & Cynodon dactylon Pers. & Upland & $1.6 \mathrm{~cd}$ \\
\hline \multirow{4}{*}{$\begin{array}{l}\text { Slum } \\
\text { (Poyati) }\end{array}$} & & & & $1.5 \mathrm{C}$ \\
\hline & Kalmi & Ipomea aquatica Forsk & Aquatic & $4.3 \mathrm{a}$ \\
\hline & Water hyacinth & Eichhornia crassipes (Mart.) Sols. & Aquatic & $3.3 \mathrm{~b}$ \\
\hline & & & & $3.8 \mathrm{~A}$ \\
\hline \multicolumn{5}{|c|}{ Dry Season } \\
\hline \multirow{3}{*}{$\begin{array}{l}\text { Floodplain } \\
\text { (Karail series) }\end{array}$} & Capsicum & Capsicum spp. & Upland & $1.7 \mathrm{c}$ \\
\hline & Cauliflower & Brassica albogabra Baily & Upland & $1.5 \mathrm{~cd}$ \\
\hline & Kalmi & Ipomea aquatica Forsk & Aquatic & $1.1 \mathrm{~d}$ \\
\hline \multirow{4}{*}{$\begin{array}{l}\text { Industrial } \\
\text { (Tejgaon series) }\end{array}$} & & & & $1.4 \mathrm{D}$ \\
\hline & Boro rice & Oryza sativa $\mathrm{L}$. & Aquatic & $2.2 \mathrm{c}$ \\
\hline & Grass & Cynodon dactylon Pers. & Upland & $2.4 \mathrm{bc}$ \\
\hline & Tomato & Lycopersicon esculentum Mill & Upland & $2.4 \mathrm{bc}$ \\
\hline \multirow{5}{*}{$\begin{array}{l}\text { Mixed } \\
\text { Poyati/Kajla/Tejgaon }\end{array}$} & & & & $2.3 \mathrm{~B}$ \\
\hline & Carrot & Daucus carota spp. Sativa & Upland & $2.2 \mathrm{c}$ \\
\hline & Grass & Cynodon dactylon Pers. & Upland & $2.6 \mathrm{~b}$ \\
\hline & Kalmi & Ipomea aquatica Forsk & Aquatic & $1.6 \mathrm{c}$ \\
\hline & Tomato & Lycopersicon esculentum Mill & Upland & $1.2 \mathrm{~d}$ \\
\hline \multirow{4}{*}{$\begin{array}{l}\text { Residential } \\
\text { (Kajla series) }\end{array}$} & & & & $1.9 \mathrm{C}$ \\
\hline & Boro rice & Oryza sativa $\mathrm{L}$. & Aquatic & $1.9 \mathrm{c}$ \\
\hline & Cabbage & Brassica oleracea & Upland & $2.6 \mathrm{~b}$ \\
\hline & Coriander & Coriandrum sativum $\mathrm{L}$. & Upland & $2.8 \mathrm{~b}$ \\
\hline \multirow{5}{*}{$\begin{array}{l}\text { Slum } \\
\text { (Poyati) }\end{array}$} & & & & $2.4 \mathrm{~B}$ \\
\hline & Bean & Lablab niger Medik & Upland & $3.8 \mathrm{ab}$ \\
\hline & Kalmi & Ipomea aquatica Forsk & Aquatic & $0.8 \mathrm{~d}$ \\
\hline & Tomato & Lycopersicon esculentum Mill & Upland & $4.2 \mathrm{a}$ \\
\hline & & & & $2.9 \mathrm{~A}$ \\
\hline
\end{tabular}


Table 5. Chromium in aquatic vs. upland plants in dry and wet seasons.

\begin{tabular}{lccc}
\hline \multirow{2}{*}{ Type of plants } & \multicolumn{2}{c}{ Season } & \multirow{2}{*}{ Mean effects } \\
\cline { 2 - 3 } & Wet & Dry & $2.0 \mathrm{X}$ \\
\hline Aquatic plants & $2.8 \mathrm{a}^{*}$ & $1.2 \mathrm{~d}$ & $2.2 \mathrm{X}$ \\
Upland plants & $2.0 \mathrm{c}$ & $2.4 \mathrm{~b}$ & \\
\hline Mean effects & $2.4 \mathrm{~A}$ & $1.8 \mathrm{~B}$ & \\
\hline
\end{tabular}

*Means separated by same lower case letter indicates significant plant $\mathrm{X}$ season interaction.

Table 6. Chromium in seasonally common aquatic and upland plants.

\begin{tabular}{|c|c|c|c|c|}
\hline $\begin{array}{l}\text { Common name } \\
\text { of plants }\end{array}$ & $\begin{array}{l}\text { Scientific name } \\
\text { of plants }\end{array}$ & $\begin{array}{l}\text { Type of } \\
\text { plants }\end{array}$ & $\begin{array}{l}\text { Sampling } \\
\text { season }\end{array}$ & $\begin{array}{l}\text { Biomass } \\
\mathrm{Cr}(\mathrm{mg} / \mathrm{kg})\end{array}$ \\
\hline \multirow{2}{*}{ Bean } & \multirow{2}{*}{ Lablab niger Medik } & \multirow{2}{*}{ Upland } & Dry & $3.8 \mathrm{a}$ \\
\hline & & & Wet & $2.2 \mathrm{~b}$ \\
\hline \multirow{3}{*}{ Grass } & \multirow{3}{*}{ Cynodon dactylon Pers. } & \multirow{3}{*}{ Upland } & & $3.0 \mathrm{~A}$ \\
\hline & & & Dry & $2.5 \mathrm{~b}$ \\
\hline & & & Wet & $1.9 \mathrm{~b}$ \\
\hline \multirow{4}{*}{ Kalmi } & \multirow{4}{*}{ Ipomea aquatica Forsk } & \multirow{4}{*}{ Aquatic } & & $2.2 \mathrm{~B}$ \\
\hline & & & Dry & $1.2 \mathrm{c}$ \\
\hline & & & Wet & $2.6 \mathrm{~b}$ \\
\hline & & & & $1.9 \mathrm{C}$ \\
\hline
\end{tabular}

\section{ACKNOWLEDGEMENTS}

The authors thank the Ministry of Science and Information Technology, People's Republic of Bangladesh for financial support and the Centre of Excellence, University of Dhaka for giving facilities to analyze the soil, plant and water samples. They also thank the Chairman of the Dept. of Soil, Water and Environment, University of Dhaka for supporting the research and providing with library, laboratory, and all other research facilities.

\section{REFERENCES}

Bharma, R.K. and M. Costa. 1992. Trace elements-aluminium, arsenic, cadmium, mercury, lead and nickel. In. Environmental Toxicants. Morton Limg $\mathrm{Kg}^{-1}$ an (ed) Pupl. Co.Von Nostrend Reinhold. New York. pp. 575-615.

Bhouyan, A.M. 1979. Effects of industrial pollution on the biology of the river Karnafuli. M. Phil. Dissertation (Unpublished). Department of Zoology, University of Chittagong, Bangladesh. pp. 65-98.

Black, C. A., D. D. Evans, L. E. Ensminger, J. L. White and F. E. Clark. 1979. Methods of soil analysis. Part 1. Physical and mineralogical properties, including statistics of measurement and sampling. American Society of Agronomy, Inc., Publisher Madison, Wisconsin, USA. pp. 545-566.

Blum, W.E.H., H. Spiegel and W.W. Wenzel. 1996. Bodenzutstandsinventur. Konception. Durchführung und Bewertung. Empfehlungen Zur Vereinheitlichung der Vorgangsweise in Österreich. Bundesministerium für Land und Forstwirtschaft. Wien. $2^{\text {nd }}$ edition. pp. 102.

Brümmer, G.W., J. Gerth and K.G. Tiller. 1988. Reaction kinetics of the adsorption and desorption of Ni, Zn and Cd by goethite: I. Adsorption and diffusion of metals. J. Soil Sci. 39: 37-52.

Chamon, A.S., W.E.H. Blum, M.H. Gerzabek, S.M. Ullah, M. Rahman and M.N. Mondol. 2005. Heavy metal uptake into crops on polluted soils of Bangladesh. II. Influence of Soil amendments. J. Comm. Soil Sci. Plant Analysis 36: 907-924. 
Cheung, K.H. and J.D. Gu. 2007. Mechanism of hexavalent chromium detoxification by microorganisms and bioremediation application potential. J. International Biodeterioration and Biodegradation 59(1): 8-15.

DOE (Department of Environment). 2002. Environmental Quality Standards for Bangladesh. Report. pp. 112-140.

Hussain, M.S. 1992. Soil classification with special reference to the soils of Bangladesh. University of Dhaka. Dhaka, Bangladesh. pp. 16-263.

Kabata-Pendias, A., A.K. Piotrowska and S. Dudka. 1993. Trace elements in legumes and monofyledors and their suitability to the assessment of soil contamination. In: Plants as Biomonotors. B. Markert, Ed.: Weinhaum: Berlin, Germany. pp. 485-494.

Kashem, M.A. and B.R. Singh. 1998. Heavy metal contamination of soil and vegetation in the vicinity of industries in Bangladesh. Water, Air and Soil Pollution 115: 347-361.

Kloke, A. 1980. Orientierungslaten fur tolerierbare Gesamtgehalte einiger Elemente in Kulturböden. Mitteilungen der VDLUFA 1-3: 9-11.

Lindsay, W.L. and W.A. Norvell. 1978. Development of a DTPA soil test for zinc, iron, manganese and copper. Soil Sci. Soc. Am. J. 42: 421.

Nuruzzaman, M., A. Islam, S.M. Ullah, M.H. Rashid and M.H. Gerzabek. 1998. Contamination of soil environment by the tannery industries. Bangladesh J. Soil Sci. 25:1-10.

Nuruzzaman, M., M.H. Gerzabek and S.M. Ullah. 1995. Studis on heavy metal and microbiological pollution of soils, sediments and water systems in and around Dhaka City. Bericht an die Österr. Akademie der Wissenschaften. ÖFZS. 1995.

Petruzzelli, G. 1989. Recycling wastes in Agriculture: Heavy metal bioavailability. Agric. Ecosyst. Environ. 27: 493-503.

Rande, P.S. 2000. Impact on Environment and Fertilizer consumption. In. Industries and Environment: A study of impact assessment. A. P. H. Publ. Corpor. New Delhi, India. pp. 91-131.

Rouse, R.D. 1979. Water quality management in pond fish culture. In: Research and Development Series No. 22, Project: AID/DSAN-G 0039, Auburn University, Alabama, USA. pp. 112.120.

Sauerbeck, D. 1982. Welche Schwermetallgehalte in Pflanzen dürfen nicht überschritten werden. um Wachstumsbeeinträchtigungen $\mathrm{zu}$ vermeiden? Landw. Forsch. Sonderheft 39. Kongressband. pp. 108-129.

Schmidtke, N.W. 1980. Trends in organic sludge utilization. Murray Moo-Young and Grahame. L. Farquhar (ed). pp. 53-78.

Sparks, D.L., A.L. Page., P.A. Helmke., R.H. Loepert., P.N. Soltanpour., M.A. Tabatabai., C.T. Johnston and M.E. Sumner. 2001. Methods of soil analysis. Volumes 1. 2 \& 3. SSSA Book Series 5. 3rd Printing. Pub. by Soil Science Society of America, Segoe Street, Madison, WI. USA. pp. 302-445.

Ullah, S.M., M. Nuruzzaman and M.H. Gerzabek. 1995. Heavy metal and microbiological pollution of water nad sediments by industrial wastes, effluents and slums around Dhaka city. In Tropical Limnology. K.H. Timotius and F. Goeltenboth (eds). Publ. Satya Wacana Christian University. Salatiga, Indonesia. pp. 179-186.

Ullah, S.M., M.H. Gerzabek., M.N. Mondol., M.M. Rashid and M. Islam. 1999. Heavy metal pollutio of soils and water and their transfer into plants in Bangladesh. In: Proc. of extended Abstracts. 5th International Conference on the Biogeochemistry of Trace Elements (Wenzel, W. W.; D.C. Adriano; B. Alloway; H.E. Doner; C. Keller; N.W. Lepp; M. Mench; R. Naidu and G.M. Pierzynski. (eds) Vienna, Austria. I: 260-61.

(Received revised manuscript on 14 August, 2013) 